\title{
PADUS, SANDALUS, GENS FADIENA. UNDERWATER SURVEYS IN PALAEO-WATERCOURSES (FERRARA DISTRICT - ITALY)
}

\author{
G. Bucci ${ }^{\mathrm{a}}$

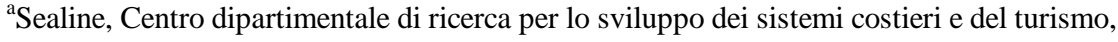 \\ Dipartimento di Architettura Università di Ferrara, ITALY; \\ Confédération Mondiale des Activités Subaquatiques. Federation ITA F07 A.CDCI., Bologna, \\ ITALY, giovibucci@yahoo.it
}

\section{Commission V}

KEY WORDS: Underwater Archaeology, Survey, Palaeo-watercourses, Roman Docks, Padus

\begin{abstract}
:
In the ambit of our program of researches on ancient rivers in Ferrara hinterland (Italy), we have been joining a Scientific - Didactic Project between Soprintendenza per i Beni Archeologici dell'Emilia Romagna, Comune di Portomaggiore Assessorato alla Cultura, CMAS A.CDCI. - Confédération Mondiale des Activités Subaquatiques Federation ITA F07 - Associazione CMAS Diving Center Italia. The Project is focused on underwater archaeological surveys in ex quarry lakes, following the Rivers Padus and Sandalus between Voghiera, Gambulaga and Portomaggiore (Ferrara District). Here we are going to introduce our most recent results, after the last immersions and a 3D bathymetrical survey completed by echo-side scan sonar in Tramonto Lake at Gambulaga, explaining the connection with remote sensing investigations and direct surveys applied to underwater archaeology of the inland water. The main submerged structure individuated is a part of wooden dock on the left side of Padus, in front of the Necropolis of Fadieni $\left(1^{\text {st }}-3^{\text {rd }}\right.$ cent. A.D.). Thanks to the study of 183 finds coming from the lake, involving students and young collaborators of the Archaeological National Museum of Ferrara, we are reconstructing the ancient landscape between Proto-Imperial Age and Late Antique.
\end{abstract}

\section{INTRODUCTION}

\subsection{The project}

The Federation ITA F07 A.CDCI. operates through scientific courses involving students directly working in the research on the field, thanks to a series of agreements and conventions with the Institutions in charge.

Since 2009 we are working on a project called Underwater archaeology of the inland water. Investigation at Tramonto Lake Gambulaga - Portomaggiore (FE - Italy) directed by who is writing with the scientific supervision of Valentino Nizzo $\mathrm{Ph} . \mathrm{D}$. Archaeologist Executive Board of the Superintendence. It is collaboration between A.CDCI., Soprintendenza per i Beni Archeologici dell'Emilia Romagna, Comune di Portomaggiore Assessorato alla Cultura with the hospitality of Agriturismo ai Due Laghi del Verginese. During our researches the diver students achieve the CMAS Certification of Archaeology diver and Archaeology Advanced Diver.

The Project is focused on underwater archaeological surveys in ex quarry lakes, following the ancient Rivers Padus and Sandalus between Voghiera, Gambulaga and Portomaggiore (Ferrara District).

We begin our studies from aero and satellite photos and geological interpretation of the site. At the same time, after a deep bibliographical research, we analyse the old cartographic documentation, checking difference and continuity of landscape and waterscape situation, across changes and modification of the environment.

We are completing our studies with 3D bathymetries and sections to have an overall diachronic vision of Delta archaeology since Protohistory to Renaissance Period, reconstructing the hydrographic system.

\subsection{The site}

The area of our investigations is located in Emilia Romagna in Ferrara District, Comune di Potomaggiore, Gambulaga, Via Verginese, at about one $\mathrm{km}$ far away from Delizia del Verginese, a Renaissance Castle.

We are working on an ex sand quarry lake with a maximum depth of $m$ 17. The artificial basin has a length of $m 600$ and a maximum width of $\mathrm{m} \mathrm{220}$. It was born during Years Eighty, because of quarry excavation in palaeo-watercourse of River Po, the ancient Padus. The phreatic zone in this land is very close to the Earth's surface (about m 1,0 depth). Figure 1.

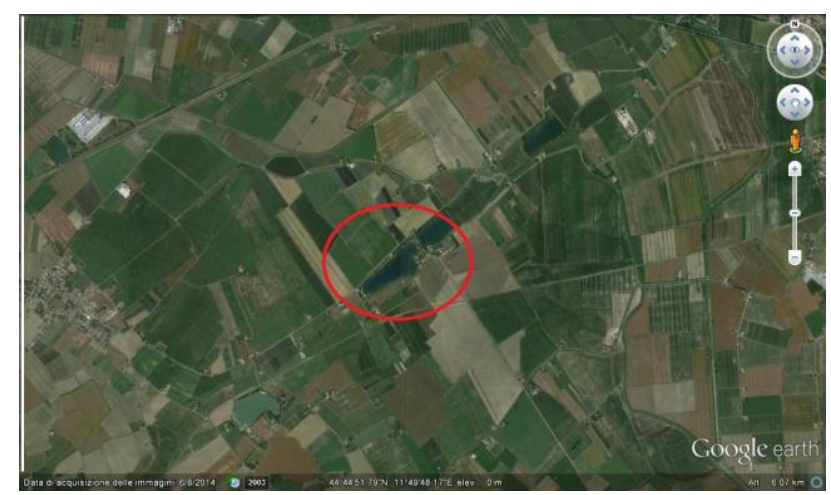

Figure 1. Google Earth satellite imagine: Tramonto Lake, Gambulaga - Portomaggiore (FE), Italy.

The old river was arriving from Northwest side, crossing Gambulaga, moving to East, creating a big meander curving to the North side, just a few meters away from the Necropolis of 
Fadieni, a great burial area dating to the $1^{\text {st }}-3^{\text {rd }}$ century A.D., occasional discovering of the Property of that land.

Rivers Padus and River Sandulus were connected in Voghiera area, a place with a great role during Roman and Late Roman Period in the Regio Octava (Berti, 2006).

This site has a high land elevation, reaching $\mathrm{m}+2$ on the sea level: a great vertical extent in comparison to the local surrounding countryside ( 0 or under the topographic 0 ). Figure 2.

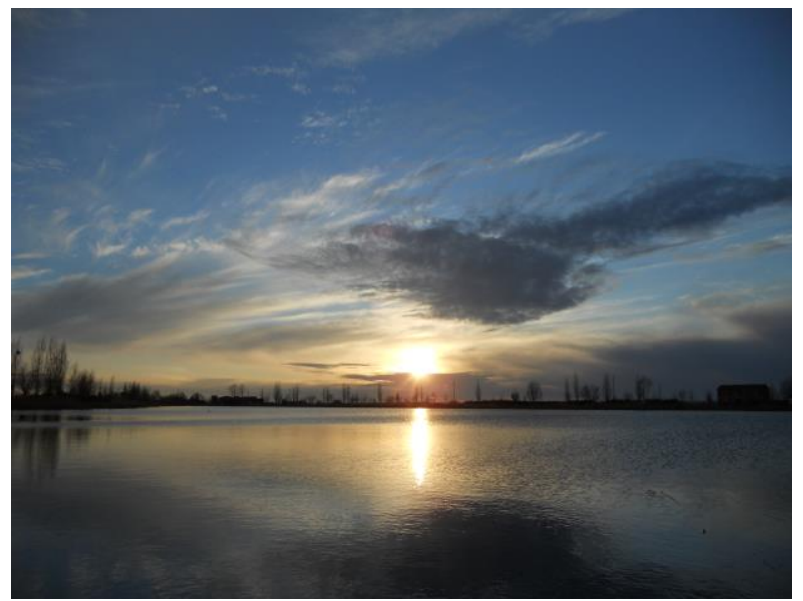

Figure 2. Gambulaga - Portomaggiore (FE), Tramonto Lake.

The context is characterized by micro hills, connected with anthropic presence, attested since Late Republican Age, until Renaissance Period.

The superficial lithology, most of all clay and silty clay, testifies some Late Roman and Mediaeval floodings with silt and sand, attested especially on the South side of the river (Stefani, 2006; Veggiani, 1992). Figure 3.

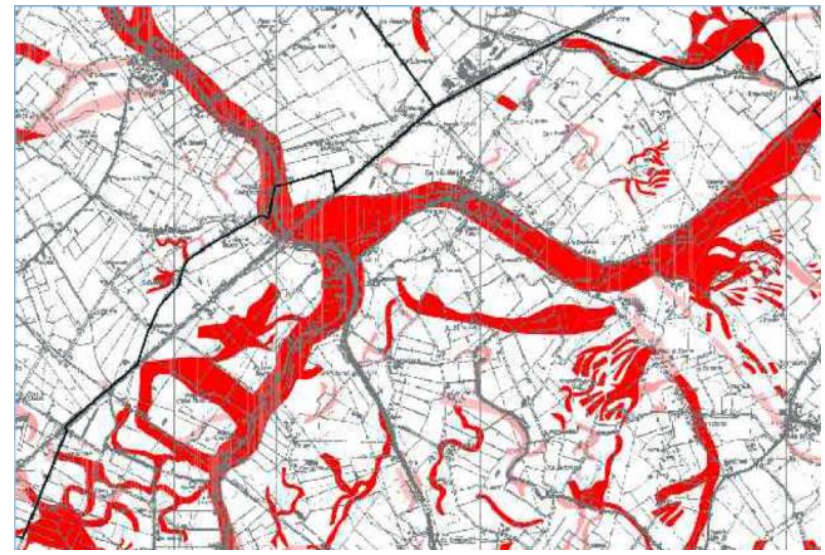

Figure 3. Gambulaga - Portomaggiore (FE), Palaeo-

watercourses and floods (extract from the map Luetti, Veronese,

Brunaldi, 2005).

The archaeological site of the necropolis has been excavated by Soprintendenza per i Beni Archeologici dell'Emilia Romagna under the direction of Fede Berti, between 2002 and 2005 (Berti, 2006), bringing to light five funerary monuments and some burials: the stele of Caius Fadienus (Cai filius) and Ambulasia Anucio (Marci filia), the stele of Lucius Pompennius Placidus (Caii filius), and Fadiena Tertia (Caii filia) with the son Pompennius Valens; the stele of Fadienus Vegetus; the monument of Marcus Fadienus Massa and Valeria Secunda and the stele of Lucius Fadienus Actor (about the necropolis: Berti, 2006 - Figure 4).

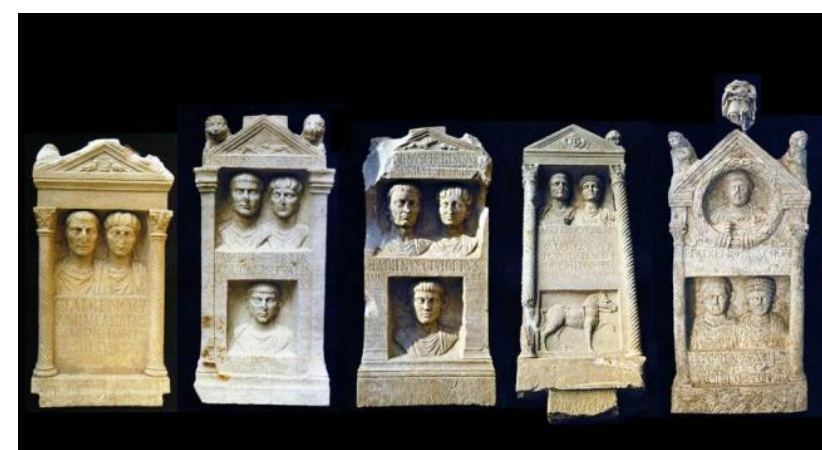

Figure 4. The stele of Fadieni (Berti, 2006).

All the monuments are obtained from calcar parallelepipeds and bear sculptures of Fadieni's faces. a family of landowners who has been living there in Late Republican and Proto Imperial Age (about the family: Scarano Ussani, 2010).

The five steles with more than two hundred findings came to light from the two excavations campaigns: a witness of Romanization process of the Delta Territory that followed the course of the ancient hydrographical system, in which Gambulaga site is included with Voghiera, Masi Torello, Ostellato and Comacchio (Bondesan, Masè, 1984; Uggeri, 1975 and 2001). Thanks to the grave goods, we have many data of a civilization with its own usages and habits, where everyday life interacts with myth and millenarian symbols related to afterlife. All the finds are on permanent exhibition at Delizia Estense del Verginese, Gambulaga .

The necropolis was covered by a big flooding of clay coming from River Padus; the monuments collapsed and were covered by alluvial sediments which preserved the site for more or less 1800 years. The surrounding area evidences anthropic traces and frequented levels.

\section{UNDERWATER RESEARCHES}

\subsection{The direct surveys}

Our first underwater section was dedicated to lakebed surveys.

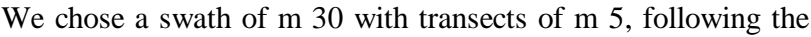
direction $200^{\circ}$ North.

The second section was focused on the positioning of topographical references and benchmarks connected one each other by guide cable, marked on the surface with buoys.

With the third session we realize photo and video documentation, followed by pegging and numeration of the main archaeological evidences and finds. Figure 5.

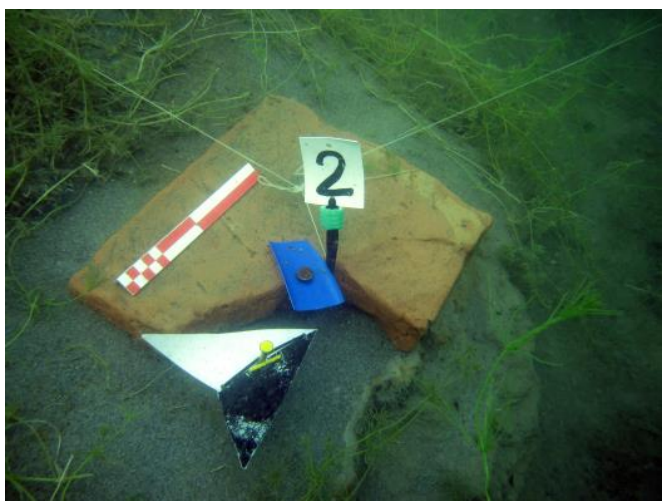

Figure 5. Gambulaga - Portomaggiore (FE), Tramonto Lake. Roman Brick with metrical reference and orientation. 
The fourth step has been to create a polygonal line with polar coordinates connected with the most important findings.

After that, with a total station reflector less, we took all the positions of the surface buoys, interfacing the data with our land benchmarks. The topographical grid has been reported on CTR (Carta Tecnica Regionale).

The positioning of benchmarks on best spots to individuate a clear stratigraphy, has been a good choice to draw sections during the immersions. The autoptic survey has been a great help to individuate micro layers and levels in relation with the anthropic frequentation of the site.

The main polygonal line measures $\mathrm{m} 250$ and it is dislocated close to North side of the Lake. The maximum depth of the archaeological findings is about $\mathrm{m} 12$.

\subsection{Indirect surveys}

The 2013 was dedicated to relief program, documentation, sampling and organization of the cataloguing of archaeological materials found during the underwater surveys.

In collaboration with Hydrosynergy, a Spin off of Alma Mater Studiorum University of Bologna we completed and indirect survey with echo sound scan sonar Humminbird 1198c SI Combo.

The team made seven 3D bathymetries and two 3D sections (North-South and West-East) elaborated with software Drdepth.se. Figures 6-7.

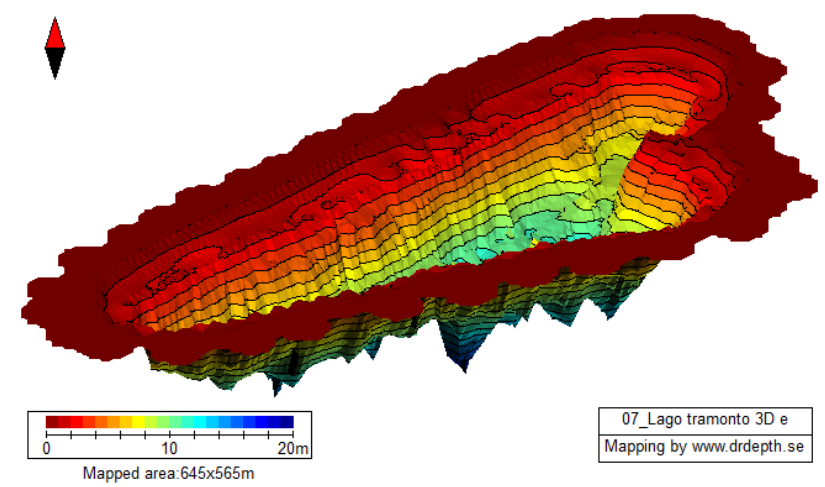

Figure 6. Gambulaga - Portomaggiore (FE), Tramonto Lake. 3D Plan view (G. Zuffi).

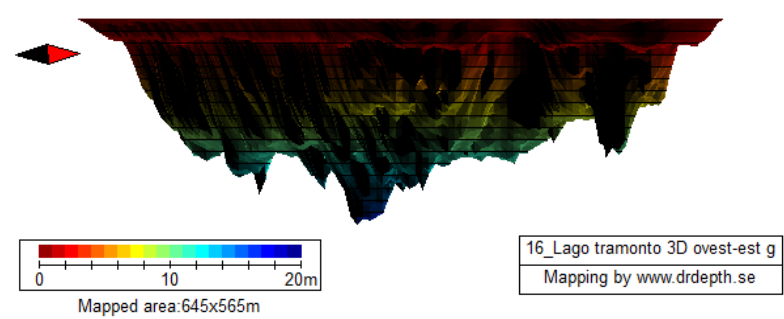

Figure 7. Gambulaga - Portomaggiore (FE), Tramonto Lake. 3D Section West-East (G. Zuffi).

From the data collected we chose a selection of twenty-five snapshots, each one of which with visual DI (down image) and SI (side image), reading on Humviewer software. From the file we have individuated 25 anomalies.

Thanks to the GPS positioning we made a joint session of investigations: boat with echo sound scan sonar on the surface and divers in immersion for a check of the anomalies.
The confirmed data are related to three main categories of findings, as the following snapshots and pictures can testify: big tree trunks (Figurers 8-9), Roman Bricks (Figures 10-11), wooden piles (Figures 12-13).

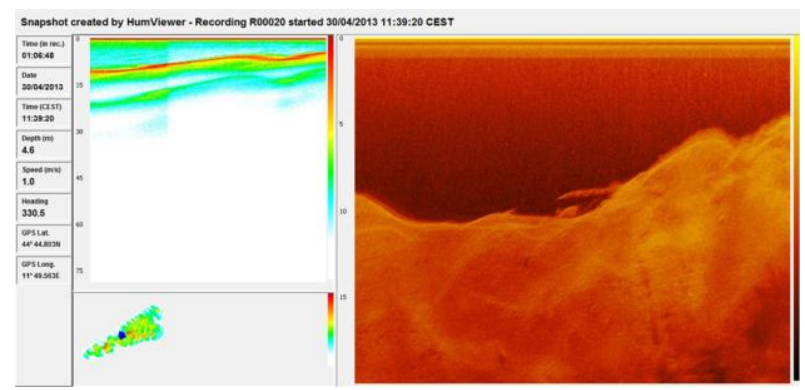

Figure 8. Gambulaga - Portomaggiore (FE), Tramonto Lake, snapshot with big tree trunks.

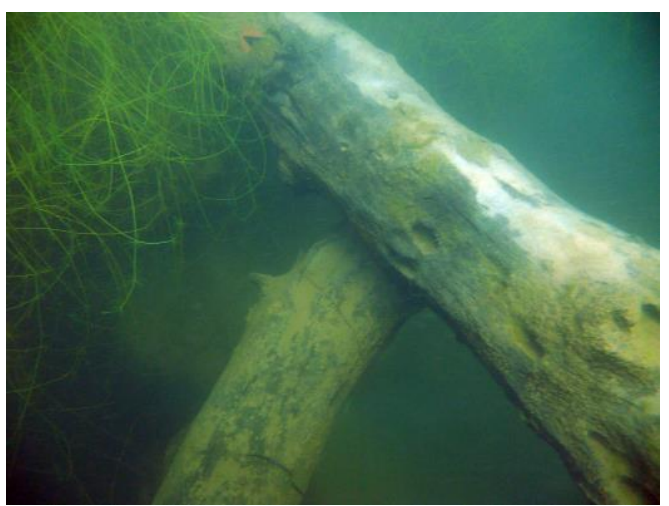

Figure 9. Gambulaga - Portomaggiore (FE), Tramonto Lake, big tree trunks.

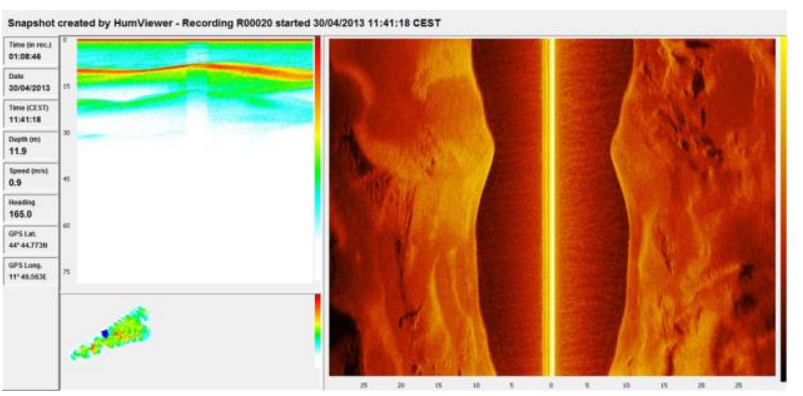

Figure 10. Gambulaga - Portomaggiore (FE), Tramonto Lake, snapshot with scattered Roman Bricks.

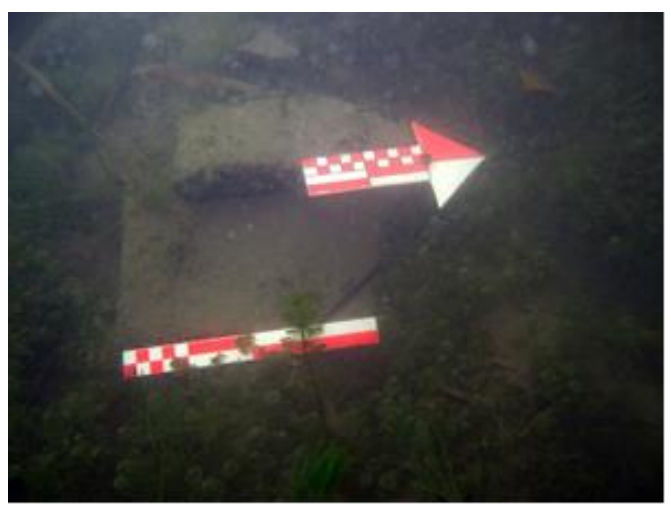

Figure 11. Gambulaga - Portomaggiore (FE), Tramonto Lake, Roman Bricks. 


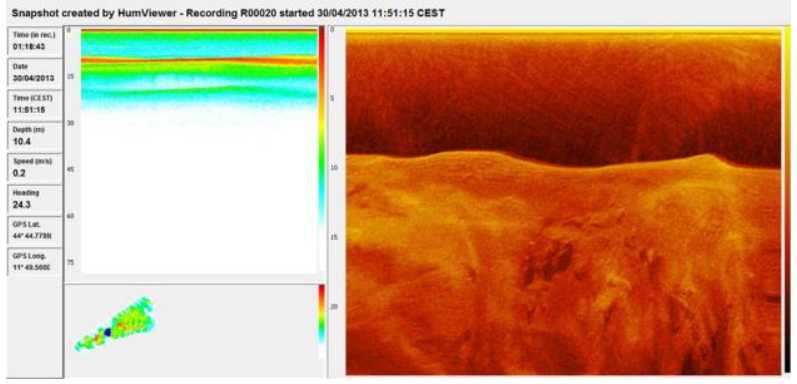

Figure 12. Gambulaga - Portomaggiore (FE), Tramonto Lake, snapshot with wooden piles.

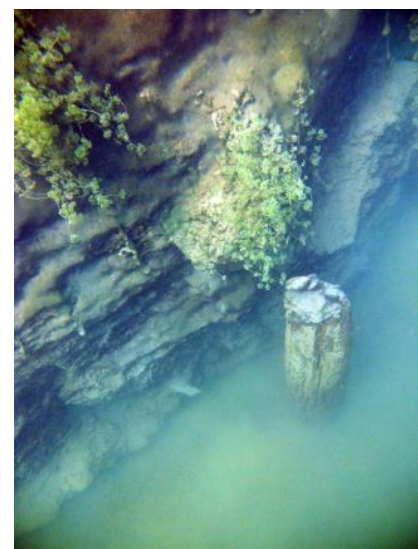

Figure 13. Gambulaga - Portomaggiore (FE), Tramonto Lake, wooden pile.

The indirect surveys revealed many anomalies not always visible during the diving sessions, because of the turbidity of the water, with a lot of melted clay in suspension and micro algae, but also for the frequent presence of filamentous algae, Alga Chara, Myriophyllum (Bucci, 2010b).

\section{THE UNDERWATER CONTEXT}

\subsection{Stratigraphy and structures}

The underwater stratigraphy is basically attested on ten Stratigraphic Units.

On the top there is US 1 , clay with reed thicket (depth m 0,00 $1,00)$ covering a level of clay with alga (US 2, m -1,00-4,00), US 3 , clay and silt with Roman Finds: bricks, pottery and wood (m 4,00-4,75); US 4, trunks and logs with heterogeneous dimensions (diameter between $\mathrm{m} 0,20-1,00$ ), most of all laying horizontally (m -4,75-7,00); US 5, pure clay (m -7,00 - -8,00); US 6, silt with sandy lens and trunks (m -8,00 - -9,00; fig.12).

Then there are some levels interested by the wooden piles (numerated as system, US 10, depth $\mathrm{m}-5-7$ ): US 7, brown silty clay, US 8 , dark grey clay, US 9 , very light beige pure clay (layers well visible on Figure 13). These three levels are crossed by the piles; on the US 7 we found the head of wood structures. Considerations about the pile system.

The piles are lined up and stands in a depth between $\mathrm{m}-5$ and -7 , quiet at the same level of the US 4, with which probably it is in connection with US 7

It is an alignment made of 11 piles (catalogued by us with a progressive numeration); the diameter of the elements is variable, with a range between $\mathrm{m} 0,07$ and 0,20 .

The piles are infixed in a planar layered level of dark grey clay, which testify the anthropic artificial layer. The tip of the piles sinks in a very compact layer of light beige pure clay, without human traces.

On the lakebed we have observed the presence of fragments of wooden planks, large pieces of bark probably acts to create a structured bank combined with vertical and horizontal elements (now partially collapsed as a result of old quarry activities ended more than 10 years).

We found also objects belonging to different classes: sporadic heterogeneous pottery fragments (sigillata, mensa, kitchen pottery,), handles and tips of amphorae, many bricks and tiles. A few pieces of glass. All data testifying the local Roman Anthropization of the site.

\subsection{Remarkable finds}

Some of the most important finds, coming directly from the context of the piles are three a fragments of Roman Tile with trade mark TPANS[IANA], attributable to the local production of tiles Tiberi Pansiana, attested in Voghiera and Gambulaga during the $2^{\text {nd }}$ century A.D. (about Pansiana: Berti, 1984; Bucci, 2012; Cornelio Cassai, 1979; Cornelio Cassai, 1984; Matijašic, 1983; Pellicioni, 2012). Figure 14.

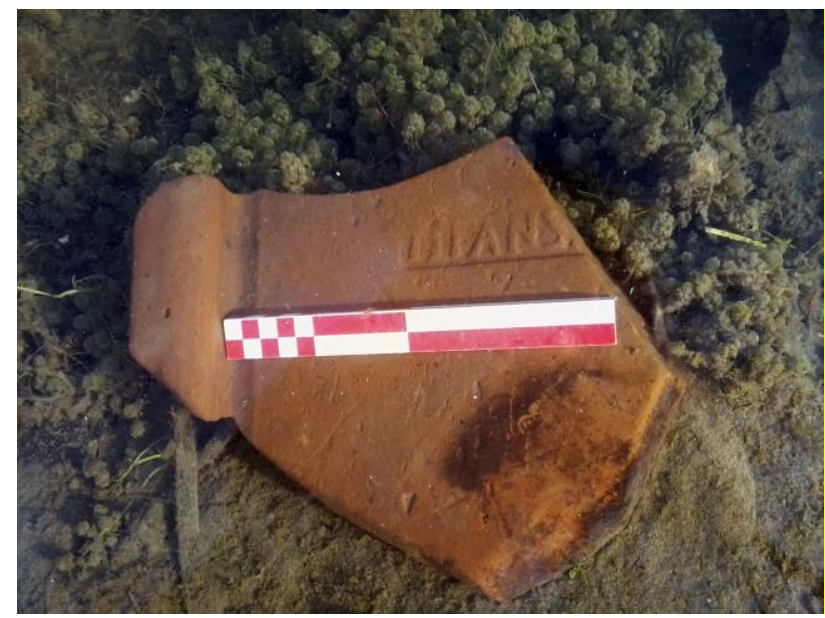

Figure 14. Fragment of Tiberi Pansiana tile from Tramonto Lake.

In the same area there was also a part of a wooden beam, with

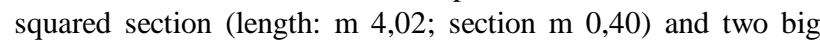
steps (m $0,20 \times 0,25 \times 0,20)$, maybe in phase with a couple of piles on the Northern side.

Not too far we found also a sigillata plate with later incisions and a flat bottom pitcher (actually in phase of studies).

\section{CONCLUSIONS}

\subsection{Interpretation hypothesis}

The alignment of wooden piles, with a parallel development to the river course, fixed on a very compact level of clay, is interpretable as the North side of the Padus.

It is a structured river bank, probably with docks, actually partially collapsed.

The wooden piles run from West to Est, they stand all at the same level and they should be connected by horizontal elements, now dispersed all around the area, as we have seen with our direct and indirect surveys. The main wharf was probably on the 
North side of the river, more or less in the middle of the structure we have detected. Figure 15 .

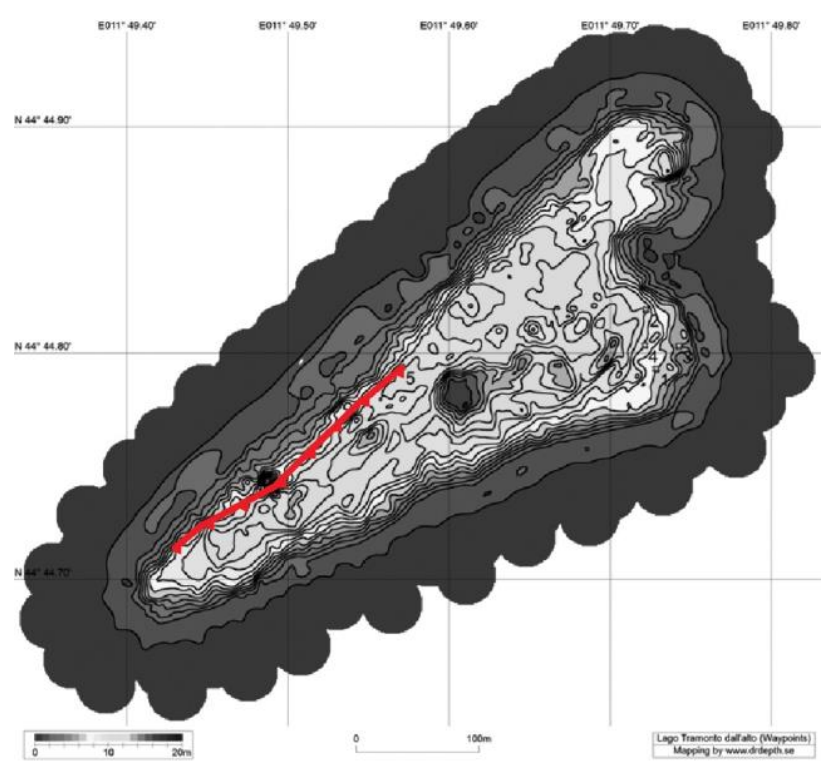

Figure 15. Gambulaga - Portomaggiore (FE), Tramonto Lake: red line indicating the ancient riverbank.

This is case of river regimentation, of anthropic control of the local waterscape, close to hydrographic confluence between the rivers Sandalus and Padus.

The river was frequented and the site should have for sure houses and commercial structures.

Traces of the settlement are attested on the South side of the river, on the Northeast side of Via Bargellesi, on the Est side of the Lake.

We could not exclude there was a saltus, a latifundium with forest, logs and trees, as the local toponomastic suggests: Rovereto (roburetum - oak forest), Alberolungo (already Ronco), literally long tree (Patitucci Uggeri, 2002).

The containment palisade was the edge of a long dock, dedicated to mooring, trade, storage, replenishment and fishing.

\subsection{Chronology}

The discovery of the three fragments of Pansiana tiles suggests us a terminus post quem, which reconduct us to the $2^{\text {nd }}$ century A.D.

The study of 183 finds coming from lake and its surrounding area, confirm a Roman presence also during the third and the fourth century A.D..

\section{Acknowledgements}

A special thanks to the Executive Board of Soprintendenza per i Beni Archeologici dell'Emila Romagna - Ferrara District, Valentino Nizzo Functionaire Archaeologist, Fede Berti Archaeologist ex Director of the National Archaeological Museum of Ferrara, Alain Rosa, Underwater Technical responsible, to Anton Slanzi Gamper, owner of the Lake, and to all the CMAS A.CDCI. Instructors and Members who has been working with me on this project.

\section{REFERENCES}

Berti F. 1984. La necropoli romana di Voghenza in "Voghenza Una necropoli di età romana nel territorio ferrarese"; Ferrara, pgs.77-202.

Berti F. 2006. (edited by), Mors immatura: I Fadieni e il loro sepolcreto, Quaderni di archeologia dell'Emilia Romagna n.16, Borgo San Lorenzo (FI).

Bondesan M., G. Masè 1984. Geomorfologia del territorio di Voghenza e di Voghiera in Voghenza in "Una necropoli di età romana nel territorio ferrarese"; Ferrara, pgs.11-22.

Bucci G., 2010a. Gambulaga 2009. Archeologia subacquea delle acque interne: bacini artificiali e controllo archeologico. Osservazioni metodologiche, tecniche e stratigrafiche, in Felix Ravenna CLVII-CLX (2001 - 2004), Ravenna, pgs.171-188.

Bucci G. 2010b. Low visibility underwater archaeological researches: Gambulaga Project 2009-2010, in "4th International Symposium on Underwater Research - March 18-20, 2010" Eastern Mediterranean University, Famagusta - Turkish Republic of Northern Cyprus, Famagusta - TRN Cyprus, .pp.2138.

Bucci G. 2012. Voghiera (FE) 2011, Fondo Fioresi: indagini archeologiche in M. T. Pellicioni, La Pansiana in Adriatico Tegole romane per navigare tra le sponde, Ferrara, pgs.123-135.

Buzzoni V. 1992. Portomaggiore attraverso i secoli, I vol. Da Santa Maria in "Porto a Portomaggiore - Aspetti storici sociali economici del territorio IX - XVI secolo”, Portomaggiore (FE).

Conti C. 2006 (edited by). Mors Inmatura - I Fadieni e il loro sepolcreto, Ufficio stampa SBAER, 22/05/2006, http://www.archeobologna.beniculturali.it/comunicati_stampa/m ors_inmatura.htm

Cornelio Cassai C. 1979. Voghenza: Antiquarium, in Annali Ist. It. Numismatica, Roma, pgs.223-226.

Cornelio Cassai C. 1984. Proposte per la definizione della carta archeologica del territorio voghentino. Vecchi e nuovi ritrovamenti in "Voghenza - Una necropoli di età romana nel territorio ferrarese"; Ferrara, pgs.23-68.

Luetti R., Veronese T., Brunaldi R. 2005. PSC 5 Comuni, Relazione Geologica.

Matijašic R. 1983. Cronografia dei bolli laterizi della figulina pansiana nelle regioni adriatiche in "Mélanges de l'Ecole française de Rome, Antiquité” T. 95, N.2. 1983. pgs. 961-995.

Patitucci Uggeri S. 2002. Carta archeologica medievale del territorio ferrarese, II, Le vie d'acqua in rapporto al nodo idroviario di Ferrara, Firenze.

Pellicioni M. T. 2012, La Pansiana in Adriatico - Tegole romane per navigare tra le sponde, Ferrara.

Scarano Ussani V.2010. Storie di uomini e terre in un sepolcreto prediale, in Ostraka, Rivista di Antichità, Anno XIX - n.1-2 Gennaio-Dicembre 2010, pgs.289-293. 
Uggeri G. 1975. La romanizzazione dell'antico delta padano, Deputazione Provinciale Ferrarese di Storia Patria. Atti e Memorie; s.III; 20, Ferrara 1975, pgs.30-52.

Uggeri G. 2001. Problemi storico-topografici del territorio di Voghenza. L'evo antico; in "L'antica diocesi di Voghenza - Le radici cristiane di Ferrara"; Portomaggiore (FE) 2001, pgs.1736.

Veggiani A. 1992. Il Delta del Po e l'evoluzione, in Atti Tav. Rotonda 1982, ACC Scienze dell'Ist. Di Bologna "Il Delta del Po" sezione geologica, Bologna, pgs.37-68. 